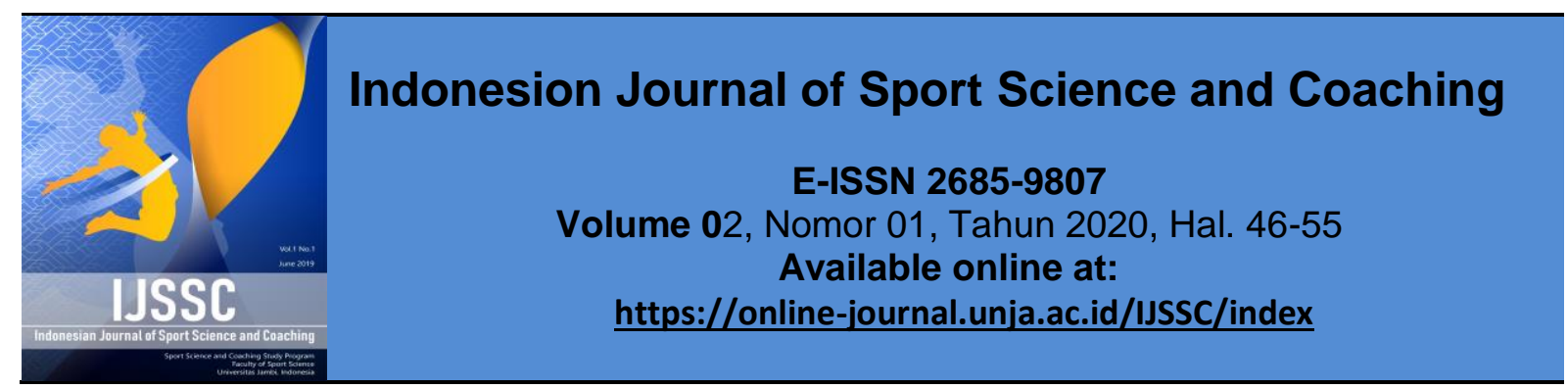

Research Article OPEN ACCESS

\title{
Penerapan E-Learning Di Era Revolusi Industri 4.0 Untuk Menekan Penyebaran Covid-19
}

\section{(The Application of E-Learning in the Era of the Industrial Revolution 4.0 to Suppress the Spread of Covid-19)}

\author{
Boy Indrayana*, Ali Sadikin
}

Universitas Jambi, Provinsi Jambi

Kampus Pinang Masak JI. Jambi Ma. Bulian KM.15 Mendalo Indah, Kec. Jaluko Kab. Muarojambi-Jambi Kode Pos 36361- Indonesia

${ }^{*}$ Corresponding Author: boyindrayana@unja.ac.id

\begin{tabular}{|c|c|}
\hline Informasi Artikel & ABSTRACT \\
\hline $\begin{array}{l}\text { Submit: } 17-11-2019 \\
\text { Diterima: } 19-02-2020 \\
\text { Dipublikasikan: } 28-02-2020\end{array}$ & $\begin{array}{l}\text { With covid-19 which has become a world pandemic by attacking } \\
215 \text { countries, educators are looking for alternatives in } \\
\text { implementing electronic-based learning or commonly called e- } \\
\text { learning. E-learning is one of the advances in the era of the } \\
\text { industrial revolution 4.0. the purpose of this study is to provide an } \\
\text { overview of the application of elearning in the era of the industrial } \\
\text { revolution } 4.0 \text { in suppressing the spread of the co-19 pandemic in } \\
\text { the Department of Sports Education and FKIP training at Jambi } \\
\text { University. The research subjects were students of the } \\
\text { Department of Sport Education and Coaching FKIP Jambi } \\
\text { University. Data collected on line through interviews through the } \\
\text { google meeting application. Data were analyzed using the } \\
\text { interactive analysis technique of Miles \& Huberman. Research } \\
\text { reports that (1) Students feel interested in the application of } \\
\text { elearning. (2) the application of e-learning makes it easy for } \\
\text { students to attend lectures. (3) Application of e-learning can } \\
\text { prevent covid-19 transmission on campus. The application of e- } \\
\text { learning has obstacles for students who live in remote areas. The } \\
\text { application of e-learning makes students independent and have } \\
\text { the courage to express opinions. } \\
\text { Keywords: e-learning, industrial revolution 4.0, Covid-19 }\end{array}$ \\
\hline Penerbit & ABSTRAK \\
\hline $\begin{array}{l}\text { Jurusan Pendidikan Olah Raga dan } \\
\text { Kepelatihan FKIP Universitas Jambi } \\
\text { Jambi- Indonesia }\end{array}$ & $\begin{array}{l}\text { Dengan adanya covid-19 yang telah menjadi pandemi dunia } \\
\text { dengan menyerang } 215 \text { negara membuat para pendidik mencari } \\
\text { alternatif dalam melaksanakan pembelajaran berbasis elektronik } \\
\text { atau biasa disebut e-learning. E-learning adalah salah satu } \\
\text { kemajuan di era revolusi industri } 4.0 \text {. tujuan penelitian ini adalah } \\
\text { untuk memberikan gambaran penerapan elearning di era revolusi } \\
\text { industri } 4.0 \text { dalam menekan penyebaran pandemi covid-19 di } \\
\text { Jurusan Pendidikan Olah raga dan kepelatihan FKIP Universitas } \\
\text { Jambi. Subyek penelitian adalah mahasiswa Jurusan Pendidikan } \\
\text { Olahraga dan Kepelatihan FKIP Universitas Jambi. Data } \\
\text { dikumpulkan secara on line melalui wawancara melalui aplikasi } \\
\text { google meeting. Data dianalisis menggunakan teknik analisis } \\
\text { interaktif Miles \& Huberman. Penelitian melaporkan bahwa (1) } \\
\text { Mahasiswa merasa tertarik dengan penerapan elearning. (2) }\end{array}$ \\
\hline
\end{tabular}



covid-19 di kampus. Penerapan e-learning memiliki kendala bagi mahasiswa yang tinggal daerah terpencil. Penerapan e-learning membuat mahasiswa menjadi mandiri dan memiliki keberanian dalam mengemukakan pendapat.

Kata kunci: e-learning, revolusi industri 4.0, Covid-19,

This Indonesian Journal of Sport Science and Coaching is licensed under a CC BY-NC-SA (Creative Commons Attribution-ShareAlike 4.0 International License)

\section{PENDAHULUAN}

Umat manusia sedang dilanda musibah pandemi Covid-19 dan berbagai negara telah melakukan isolasi (Wahyudin Darmalaksana et al., 2020). Covid-19 telah menyerang 215 negara di dunia termasuk Indonesia. Hal ini menjadi tantang tersendiri bagi lembaga pendidikan dalam melaksanakan pembelajaran (Jamaluddin et al., 2020). Untuk menekan penyebaran covid-19 pemerintah telah mengeluarkan kebijakan bagi perguruan tinggi untuk melakukan pembatasan sosial (social distancing) dan menjaga jarak fisik (physical distancing). Belajar dari rumah, bekerja dirumah dan beribadah dirumah (Jamaluddin et al., 2020). Perguruan tinggi dituntun untuk dapat menyelenggarakan pembelajaran secara daring atau on line (Firman \& Rahayu, 2020).

Teknologi informasi dan komunikasi saat ini memegang peranan penting dalam dunia pendidikan. Metode pembelajaran secara on line atau e-learning telah menggeser pembelajaran secara konvensional. Pada era revolusi industri 4.0 diman IOT (Internet of Things) memegang peranan penting dalam segala hal. Dunia pendidikan harus mengikuti perkembangan tersebut. Banyak manfaat yang didapatkan diantaranya adalah pembelajaran tidak terikat oleh ruang dan waktu. Dapat dilakukan dimana saja dan kapan saja (Pangondian et al., 2019).

Penerapan e-learning di era revolusi industri 4.0 telah menjawab permasalahan pembelajaran di masa pandemi covid-19. Dengan intruksi yang jelas mahasiswa dapat melaksanakan e-learning dengan baik bahkan mandiri. Mahasiswa juga terlihat aktif dalam mengikuti perkuliahan secara daring. Mahasiswa berani memberikan pendapat dan merespon positif terhadap pembelajaran menggunakan e-learning (Astuti \& Febrian, 2019). Walaupun e-learning dapat dijadikan solusi bagi pembelajaran di era revolusi industri 4.0 untuk menekan penyebaran covid-19 namun ada hambatan yang perlu diperhatian. Hambatan itu misalnya lemahnya sinyal di daerah tertentu dan terbatasnya kuota internet menjadi aspek yang mengganggu dalam penerapan e-learning di daerah tertentu (Jamaluddin et al., 2020).

E-learning merupakan kependekan dari electronic learning adalah pembelajaran yang memanfaatkan media teknologi seperti internet, interactive tv, audio vidio tape, CD-ROM untuk mengirimkan materi pembelajaran dimana saja dan kapan saja (Astuti \& Febrian, 2019). E-learning adalah suatu sistem yang diharapkan bukan 
sekedar menggantikan metode dan materi pembelajaran konvensional tetapi dapat menambah inovasi metode dan strategi baru dalam proses pembelajaraan masa kini. Penerapan e-learning adalah suatu media baru yang dapat mengatasi sikap pasif mahasiswa, menambah gairah belajar, memungkinkan berinteraksi langsung dan memungkinkan mahasiswa belajar secara mandiri (Nana \& Surahman, 2019).

Bentuk pembelajaran di perguruan tinggi termasuk Universitas Jambi dalam mencegah penyebaran Covid-19 adalah e-learning. E-learning merupakan pembelajaran jarak jauh yang memanfaatkan internet sebagai media komunikasi secara on line (Yazdi et al., 2012). E-learning telah dimulai sejak tahun 1970. Berbagai istilah telah digunakan antara lain onlinelearning, internet-enabled learning, virtual learning, dan web-based learning. Ada 3 syarat yang penting dalam kegiatan belajar e-learning yaitu kegiatan pembelajaran dilakukan melalui jaringan internet, tersedianya dukungan layanan belajar bagi peserta didik misalnya external harddisk, flaskdisk, CD-ROM, dan tersedianya dukungan layanan tutor yang dapat membantu peserta didik apabila megalami kesulitan (Hartanto, 2016). Penggunaan internet dan teknologi multimedia mampu merombak cara penyampaian pengetahuan dan dapat menjadi alternatif pembelajaran yang dilaksanakan dalam kelas tradisional (Zhang et al., 2004). E-learning merupakan proses belajar mengajar yang dapat mempertemukan dosen dan mahasiswa dalam interaksi kelas virtual dengan bantuan internet (Kuntarto, 2017).

Penerapan e-learning membutuhkan dukungan perangkat mobile seperti hand phone android, laptop, komputer, dan tablet yang digunakan untuk mengakses internet kapan saja dan dimana saja (Gikas \& Grant, 2013). Pada masa WFH (Work From Home) Pendidikan Tinggi diperintahkan melaksanakan pembelajaran dengan e-learning dari rumah masing-masing sehingga mengurangi pertemuan fisik (W. Darmalaksana, 2020). E-learning sudah menjadi tuntutan dunia pendidikan sejak beberapa tahun terakhir (He et al., 2019). Pembelajaran on line dibutuhkan dalam pembelajaran di era revolusi industri 4.0 (Pangondian et al., 2019; Sadikin \& Hakim, 2019).

Penggunaan teknologi mobile mempunyai sumbangan besar dalam lembaga pendidikan, termasuk di dalamnya adalah pencapaian tujuan pembelajaran jarak jauh (Jamaluddin et al., 2020). Berbagai media juga dapat digunakan untuk mendukung pelaksanaan pembelajaran secara daring. Misalnya kelas-kelas virtual menggunakan layanan Google Classroom, Edmodo, dan Schoology (Abidin et al., 2020; Sicat, 2015). dan applikasi pesan instan seperti WhatsApp (So, 2016). Pembelajaran secara daring bahkan dapat dilakukan melalui media social seperti Facebook dan Instagram (Kumar \& Nanda, 2019). Pembelajaran daring menghubungkan peserta didik dengan sumber belajarnya (database, pakar/instruktur, perpustakaan) yang secara fisik terpisah atau bahkan berjauhan namun dapat saling berkomunikasi, berinteraksi atau berkolaborasi (secara langsung/synchronous dan secara tidak langsung/asynchronous). Penerapan elearning merupakan bentuk pembelajaran jarak jauh yang memanfaatan teknologi telekomunikasi dan informasi, misalnya internet, CD-ROOM (Sadikin et al., 2020; Staker, 2011)Tujuan dari penelitian ini adalah untuk memperoleh gambaran penerpanan e-learning di era revolusi industri 4.0 dalam menekan penyebaran Covid-19 pada Jurusan Pendidikan Olahraga dan Kepelatihan FKIP Universitas Jambi. 


\section{METODE PENELITIAN}

Dalam penelitian ini menggunakan jenis penelitian kualitatif. Tujuan dari penelitian ini adalah untuk dapat menggambarkan sejelas-jelasnya penerapan elearning di era revolusi industri 4.0 ini dalam menekan penyebaran covid-19 pada Jurusan Pendidikan olahraga dan kepelatihan FKIP Universitas Jambi. Dalam rangka mengurangi kerumunan, mengatur jarak dan membantasi kontak antara dosen dan mahasiswa di kampus. E-learning yang dimaksud dalam penelitian ini adalah pembelajaran jarak jauh menggunakan internet yang dapat diakses dimana saja dan kapan saja melaui Hand phone android, laptop maupun gadget lainnya. Penelitian dilakukan dengan menyebarkan instrumen survei kepada mahasiswa Jurusan Pendidikan Olah raga dan kepelatihan FKIP Universitas Jambi. Ada sebanyak 90 orang mahasiswa yang merespon terhadap survei yang telah disebarkan. Data kemudian dikelompokan berdasarkan tiga kategori respon mahsiswa. (1) Setuju dengan penerapan e-learning; (2) Tidak setuju dengan penerapan e-learning; (3) Ragu dengan pelaksanaan e-learning.

Subjek penelitian adalah mahasiswa Jurusan Pendidikan Olahraga dan Kepelatihan FKIP Universitas Jambi telah melaksanakan pembelajaran e-learning, dan dikelompokkan berdasarkan respon subjek penelitian. Di dapatkan 12 orang subjek penelitian, 4 orang mahasiswa angkatan 2017, 4 orang mahasiswa angkatan 2018, dan 4 orang mahasiswa angkatan 2019, 8 orang mahasiswa berjenis kelamin laki-laki dan 4 orang mahasiswa berjenis kelamin perempuan. Pengumpulan data dilakukan melalui wawancara via telpon dan atau zoom cloud meeting. Aspek-aspek yang ditanyakan dalam wawancara adalah: (1) Mahasiswa merasa tertarik dengan penerapan elearning. (2) Penerapan e-learning memudahkan mahasiswa dalam mengikuti perkuliahan. (3) Penerapan e-learning dapat mencegah penularan covid19 di kampus. Analisis data penelitian dilakukan menggunakan model analisis Miles \& Huberman yang terdiri dari tiga tahapan, yaitu reduksi data, display data, serta penarikan dan verifikasi kesimpulan (Miles et al., 1994).

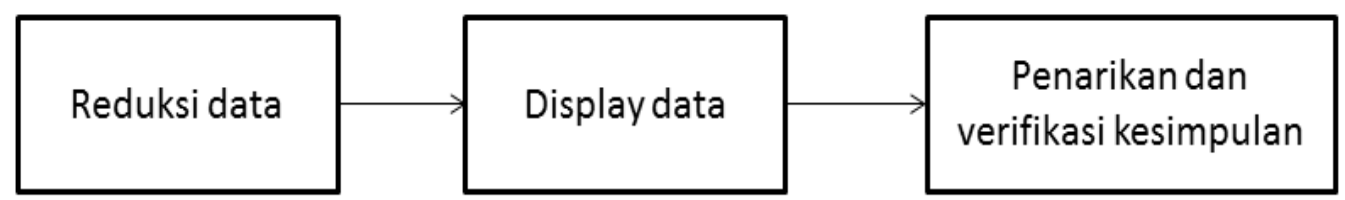

Gambar 1: Tahapan Analisis data penelitian

Analisis data penelitian tahap reduksi data merupakan tahap mengumpulkan seluruh informasi yang dibutuhkan dari hasil wawancara lalu di kelompokkan datanya. Tahap display data merupakan pemaparan data yang diperlukan dalam penelitian dan yang tidak perlu dibuang. Tahap penarikan dan verifikasi kesimpulan adalah tahap interpretasi data penelitian untuk ditarik kesimpulan berdasarkan fenomena yang didapatkan (Miles et al., 1994). 


\section{HASIL DAN PEMBAHASAN}

\section{Minat Mahasiswa terhadap penerapan e-learning}

Pengguna internet di Indonesia terus mengalami peningkatan hal ini dipengaruhi oleh kemajuan teknologi informasi dan komunikasi, jaringan internet, harga hand phone android yang semakin murah dan gaya hidup (Rahadian, 2017). Ada 62,41\% penggunan internet di Indonesia telah memiliki telepon pintar atau smartphone dan ada $20,05 \%$ rumah tangga telah memiliki komputer dirumahnya (BPS, 2019). Data in membuktikan bahwa walaupun mahasiswa tidak memiliki laptop atau komputer tetapi mereka telah memiliki telepon pintar. Survei melaporkan bahwa dari subyek penlitian mahasiswa Jurusan Pendidikan Olah raga dan Kepelatihan FKIP Universitas Jambi bahwa 50 orang telah memiliki telepon pintar dan laptop. 40 orang subyek hanya memiliki telepon pintar saja.

Minat mahasiswa terhadap penerapan e-learning di Jurusan Pendidikan Olah raga dan Kepelatihan FKIP Universitas Jambi cukup tinggi. Dari 90 orang yang di wawancarai 60 orang mahasiswa (66\%) menjawab mereka berminat belajar dengan e-learning. 19 orang mahasiswa (21\%) menjawab cukup berminat dan 11 orang mahasiswa (12\%) menjawab tidak berminat. Mereka yang menjawab berminat terhadap pembelajaran menggunakan e-learning dengan alasan pembelajaran secara daring lebih fleksibel waktu dan tempat yang digunakan. Hal ini sesuai dengan hasil penelitian bahwa e-learning menyelenggarakan pembelajaran yang tidak terikat ruang dan waktu dapat diselenggarakan kapan saja dan dimana saja (Wahyudin Darmalaksana et al., 2020; Pangondian et al., 2019). Dengan e-learning mahasiswa dan dosen memungkinkan untuk berkomunikasi dalam tempat yang berbeda (Yazdi et al., 2012). Dengan e-learning memunngkinkan mahasiswa dan dosen bertemu dalam kelas-kelas virtual untuk berinteraksi dalam mencapai tujuan pembelajaran (Kuntarto, 2017).

Dengan e-learning mahasiswa lebih berani dalam bertanya dan mengemukakan pendapat. Hal ini seperti laporan penelitian (Astuti \& Febrian, 2019) bahwa e-learning membuat mahasiswa menjadi berani bertanya dan mengutarakan gagasan serta ide-ide cemerlang. Keberadaan dosen yang jauh dari mahasiswa secara fisik membuat mahasiswa tidak takut mengungkapkan pendapat dan ide-ide kreatif mereka. Kondisi ini menyebabkan mahasiswa menjadi nyaman dalam berkomunikasi (Sun et al., 2008). Lebih lanjut, dengan e-learning mahasiswa menjadi tidak canggung dan pada akhirnya membuat mereka berani berekspresi dalam bertanya dan menjawab persoalan dalam proses pembelajaran daring secara bebas. Penggunaan smartphone dan laptop dalam pembelajaran daring dapat meningkatkan hasil belajar peserta didik (Anggrawan, 2019; Muhaimin et al., 2019). Setiap mahasiswa membutuhkan rasa kebebasan (freedom), kemandirian (needs for autonomy) dan kepercayaan (trust). Setiap mahasa yang otonom tidak akan selalu bergantung dengan dosen dalam mengikuti pembelajaran. Setiap mahasiswa 
membutuhkan rasa dirinya merupakan bagian dari suatu komunitas dan berinteraksi dengan komunitas itu (needs for realtedness) (Risdianto, 2019).

Mereka juga ada yang menjawab lebih menghemat biaya makan dan kos karena tinggal di daerah masing-masing. Pembelajaran dengan e-learning lebih murah karena dapat dilakukan dari rumah masing-masing (Risdianto, 2019). Pembelajaran dengan e-learning juga dapat membuat mahasiswa menjadi mandiri dan berani berinovasi. Banyak biaya yang dapat dihemat dari pembelajaran dengan e-learning. Biaya transportasi ke tempat belajar, akomodasi selama belajar seperti biaya kos dan biaya makan. Biaya sewa proyektor, spidol, kursi, papan tulis, listrik, alat tulis, kertas dan buku (Wibowo, 2009). Sedangkan mahasiswa yang menjawab penerapan e-learning dalam perkuliahan daring kurang berminat dan tidak berminat dengan alasan sulitnya sinyal internet di daerah mereka tinggal. Mengingat ketika pembelajaran on line diterapkan mahasiswa kebanyakan pulang kampung masingmasing. Lebih lanjut mereka yang kurang berminat dan tidak berminat dalam penerapan e-learning mengingat minimnya kuota internet yang mereka miliki. Sehingga mereka kesulitan dalam mengakses pembelajaran daring. E-learning memiliki kekurangan boros dalam penggunaan kuota internet dan penggunaan zoom cloud meeting kurang efektif bila dipakai lebih dari 20 orang mahasiswa (Naserly, 2020). Penerapan e-learning akan terkendala bila layanan internet lemah dan instruksi dosen kurang dipahami oleh mahasisa (Astuti \& Febrian, 2019).

\section{Penerapan e-learning memudahkan mahasiswa dalam mengikuti perkuliahan}

Penerapan e-learning memudahkan mahasiswa dalam mengikuti perkuliahan. Mereka cukup dengan menggunakan handphone android mereka sudah dapat mengakses perkuliahan secara on line. Dari 90 subyek penelitian 67 orang mahasiswa (74\%) menjawab mudah menggunakan aplikasi e-learning dalam proses perkuliahan daring. Ada 10 orang mahasiswa (12\%) menjawab cukup sulit dalam menggunakan aplikasi e-learning. Ada 13 orang mahasiswa (14\%) menjawab mengalami kesulitan dalam menggunakan aplikasi e-learning dalam proses perkuliahan daring. Dengan e-learning pembelajaran menjadi fleksibel baik dari segi waktu, metode, dan tempat. Hal ini menjadi kemudahan tersediri bagi mahasiswa dan dosen (W. Darmalaksana, 2020).

Akan tetapi bagi sebagain mahasiswa mereka merasakan kesulitan dalam mengakses e-learning. Ada yang disebabkan karena jaringan internet yang lemah, ada yang menjawab dikarenakan kurang familiar dengan aplikasi e-learning seperti zoom cloud meeting, google clasroom, moodle, edmodo dan lainnya. Penerapan elearning memiliki kendala lemahnya sinyal dan penggunaan zoom cloud meeting yang mengalami gangguan ketika lebih dari 20 orang yang mengaksesnya (Astuti \& Febrian, 2019). Perlu adanya tutor yang dapat mengajarkan mahasiswa dalam menggunakan e-learning (Pangondian et al., 2019). Sebab selama ini di Universitas Jambi mahasiswa tidak dilatih dalam penggunaan e-learning. Kebanyakan dari 
mereka belajar otodidak dan belajar dari teman sebaya. Hal inilah yang membuat mahasiswa mengalami kesulitan dalam penggunaan e-learning.

Hasil penelitian juga melaporkan bahwa tidak sedikit mahasiwa yang kesulitan dalam memahami materi perkuliahan yang diberikan secara daring. Bahan ajar biasa disampaikan dalam bentuk bacaan yang tidak mudah dipahami secara menyeluruh oleh mahasiswa. Mereka berasumsi bahwa materi dan tugas tidak cukup karena perlu penjelasan secara langsung oleh dosen (Sadikin \& Hakim, 2019). Penerapan e-learning seperti googel meet, google clasroom juga memiliki kelemahan dengan gambar yang pecahh apabila terlalu banyak yang mengakses, dan tampilan materi menjadi terganggu, dan suara menjadi tidak terdengar jelas (Naserly, 2020).

\section{Penerapan e-learning dapat mencegah penularan covid-19 di kampus}

Dengan penerapan e-learning di Jurusan Pendidikan Olah raga dan Kepelatihan FKIP Universitas Jambi menjadi solusi terhadap permasalah penyebaran Covid-19. Dengan penerapan e-learning 85 orang mahasiswa (94\%) menjawab dapat menekan penyebaran Covid-19 di Kampus. 5 orang mahasiswa $(6 \%)$ menjawab ragu-ragu dikarenakan pada daerah yang sulit sinya mereka akan ke kecamatan untuk berkumpul mencari sinya internet. Mengingat Covid-19 merupakan jenis virus yang mudah menyebar dan cepat serta sulit dideteksi dari satu orang ke orang lainnya. Virus ini menyerang sistem imun dan respirasi manusia terutama yang sudah memiliki penyakit bawaan akan mudah mengalami kritis (Rothan \& Byrareddy, 2020). Untuk menekan penyebaran Covid-19 harus menghindari kerumunan massal, menghindari kontak langsung dengan penderita Covid-19, dan mengatur jarak serta mencuci tangan dan memakai masker (Caley et al., 2008). Memperhatikan jaga jarak dengan penderita maupun orang lain dan menghidari kontak langusng disebut social distancing (Group, 2006).

Beberapa langkah kebijakan dilakukan Universitas Jambi sebagai usaha menekan penyebaran Covid-19 di lingkungan kampus yaitu salah satunya menerapkan pembelajaran menggunakan e-learning (Anonim, 2020). Pembelajaran dengan e-learning memunngkinkan mahasiswa dan dosen bertemu di kelas virtual sehingga tidak perlu lagi bertemu dan berkerumun di lingkungan kampus (Astuti \& Febrian, 2019; Jamaluddin et al., 2013). Dengan e-learning memuculkan sikap social distancing sebagai upaya pembelajaran di era pandemi covid-19 (Firman \& Rahayu, 2020). WHO merekomendasikan menjaga jarak dapat menekan penyebaran covid19 (Group, 2006).

\section{KESIMPULAN}

Penerapan e-learning di era revolusi industri 4.0 dibutuhkan dalam rangka menekan penyebaran Covid-19 di Kampus, maka dari itu Jurusan Pendidikan Olahraga dan Kepelatihan FKIP Universitas Jambi menerapkan e-learning sebagi jawaban akan permasalah tersebut. Hasil penelitian melaporkan bahwa mahasiswa 
tertarik dengan penerapan e-learning, mahasiswa merasakan kemudahanan dalam perkuliahan karena dapat diakses dimana saja dan kapan saja, penyebaran covid-19 di Universitas Jambi dapat ditekan. Dengan e-learning terjadi social distascing dan physical distancing. Pembelajaran dengan e-learning dapat membuat mahasiswa belajar mandiri dan berani berpendapat serta menjadi aktif. Ada kelemahan di dalam pembelajaran e-learning yaitu sinyal internet di daerah pelosok, kuota yang terbatas dan sulitnya pengawasan mahasiswa sering kali menjadi tantangan tersendiri.

\section{DAFTAR PUSTAKA}

Abidin, Z., Rumansyah, \& Arizona, K. (2020). Pembelajaran Online Berbasis Proyek Salah Satu Solusi Kegiatan Belajar Mengajar Di Tengah Pandemi Covid-19. Jurnal IImiah Profesi Pendidikan, 5(1), 64-70. https://doi.org/https://doi.org/10.29303/JIPP.V5l1.111

Anggrawan, A. (2019). ANALISIS DESKRIPTIF HASIL BELAJAR PEMBELAJARAN TATAP MUKA DAN PEMBELAJARAN DARING MENURUT GAYA BELAJAR MAHASISWA. Jurnal MATRIK, 18(2), 339-346. https://doi.org/https://doi.org/10.30812/matrik.v18i2.411

Anonim. (2020). SE-REKTOR-NOMOR-22-TH-2020.pdf (p. 1). Universitas Jambi. https://www.unja.ac.id/notice/surat-edaran-tentang-pelaksanaan-proses-belajarmengajar-unja-secara-daring/

Astuti, P., \& Febrian, F. (2019). Blended Learning Syarah: Bagaimana Penerapan dan Persepsi Mahasiswa. Jurnal Gantang, 4(2), 111-119. https://doi.org/10.31629/jg.v4i2.1560

Caley, P., Philp, D. J., \& McCracken, K. (2008). Quantifying social distancing arising from pandemic influenza. Journal of the Royal Society Interface, 5(23), 631-639. https://doi.org/https://doi.org/10.1098/rsif.2007.1197

Darmalaksana, W. (2020). WhatsApp Kuliah Mobile. Fakultas Ushuluddin UIN Sunan Gunung Djati Bandung, 1-7.

Darmalaksana, Wahyudin, Hambali, R. Y. A., Masrur, A., \& Muhlas. (2020). Analisis Pembelajaran Online Masa WFH Pandemic Covid-19 sebagai Tantangan Pemimpin Digital Abad 21. UIN Sunan Gunung Djati Bandung, 1(1), 1-12.

Firman, F., \& Rahayu, S. (2020). Pembelajaran Online di Tengah Pandemi Covid-19. Indonesian Journal of Educational Science (IJES), 2(2), 81-89. https://doi.org/10.31605/ijes.v2i2.659

Gikas, J., \& Grant, M. M. (2013). Mobile computing devices in higher education: Student perspectives on learning with cellphones, smartphones \& social media. The Internet and Higher Education, 19, 18-26. https://doi.org/https://doi.org/10.1016/j.iheduc.2013.06.002

Group, W. H. O. W. (2006). Nonpharmaceutical interventions for pandemic influenza, national and community measures. Emerging Infectious Diseases, 12(1), 88. https://doi.org/10.3201/eid1201.051371

Hartanto, W. (2016). Penggunaan E-Learning Sebagai Media Pembelajaran. Jurnal Pendidikan Ekonomi, 10(1).

He, W., Xu, G., \& Kruck, S. E. (2019). Online IS education for the 21st century. Journal of Information Systems Education, 25(2), 1.

Jamaluddin, D., Ratnasih, T., Gunawan, H., \& Paujiah, E. (2013). Pembelajaran Daring Masa Pandemik Covid-19 Pada Calon Guru: Hambatan, Solusi Dan 
Proyeksi. Journal of Chemical Information and Modeling, 53(9), 1-10. https://doi.org/10.1017/CBO9781107415324.004

Jamaluddin, D., Ratnasih, T., Gunawan, H., \& Paujiah, E. (2020). Pembelajaran Daring Masa Pandemik Covid-19 Pada Calon Guru: Hambatan, Solusi dan Proyeksi. Karya Tulis IImiah UIN Sunan Gunung Djjati Bandung, 1-10. http://digilib.uinsgd.ac.id/30518/

Kumar, V., \& Nanda, P. (2019). Social media in higher education: A framework for continuous engagement. International Journal of Information and Communication Technology Education (IJICTE), 15(1), 97-108.

Kuntarto, E. (2017). Keefektifan Model Pembelajaran Daring dalam Perkuliahan Bahasa Indonesia di Perguruan Tinggi. Indonesian Language Education and Literature, 3(1), 99-110. https://doi.org/10.24235/ileal.v3i1.1820

Miles, M. B., Huberman, A. M., \& Saldaña, J. (1994). Qualitative Data Analysis. Sage Publications Sage CA: Los Angeles, CA.

Muhaimin, M., Habibi, A., Mukminin, A., Saudagar, F., Pratama, R., Wahyuni, S., Sadikin, A., \& Indrayana, B. (2019). A Sequential Explanatory Investigation of TPACK: Indonesian Science Teachers' Survey and Perspective. Journal of Technology and Science Education, 9(3), 269-281. https://doi.org/http://dx.doi.org/10.3926/jotse.662

Nana, N., \& Surahman, E. (2019). Pengembangan Inovasi Pembelajaran Digital Menggunakan Model Blended POE2WE di Era Revolusi Industri 4.0. Prosiding SNFA (Seminar Nasional Fisika Dan Aplikasinya), 4, 82. https://doi.org/10.20961/prosidingsnfa.v4i0.35915

Naserly, M. K. (2020). IMPLEMENTASI ZOOM, GOOGLE CLASSROOM, DAN WHATSAPP GROUP DALAM MENDUKUNG PEMBELAJARAN DARING (ONLINE) PADA MATA KULIAH BAHASA INGGRIS LANJUT (Studi Kasus Pada 2 Kelas Semester 2, Jurusan Administrasi Bisnis, Fakultas Ekonomi dan Bisnis, Universitas Bina Sa. Aksara Public, 4(2), 155-165.

Pangondian, R. A., Paulus, S. I., \& Nugroho, E. (2019). Faktor - Faktor Yang Mempengaruhi Kesuksesan Pembelajaran Daring Dalam Revolusi Industri 4.0. Seminar Nasional Teknologi Komputer \& Sains (SAINTEKS), 56-60. https://seminar-id.com/semnas-sainteks2019.html

Rahadian, D. (2017). Teknologi informasi dan komunikasi (tik) dan kompetensi teknologi pembelajaran untuk pengajaran yang berkualitas. TEKNOLOGI PEMBELAJARAN, 2(1). https://doi.org/https://doi.org/10.31980/tp.v2i1.114

Risdianto, E. (2019). Analisis pendidikan indonesia di era revolusi industri 4.0. Bengkulu: Universitas Bengkulu. Diakses Dari Https://Www. Researchgate. Net/Profile/Eko_Risdianto/Publication/332415017_ANALISIS_PENDIDIKAN_IN DONESIA_DI_ERA_REVOLUSIIINDUSTRI_40/Links/5cb4509b4585156cd7993 519/ANALISIS-PENDIDIKAN-INDONESIA-DI-ERA-REVOLUSI-.

Rothan, H. A., \& Byrareddy, S. N. (2020). The epidemiology and pathogenesis of coronavirus disease (COVID-19) outbreak. Journal of Autoimmunity, 102433. https://doi.org/https://doi.org/10.1016/j.jaut.2020.102433

Sadikin, A., \& Hakim, N. (2019). Pengembangan Media E-Learning Interaktif Dalam Menyongsong Revolusi Industri 4.0 Pada Materi Ekosistem Untuk Siswa SMA. BIODIK, 5(2), 131-138. https://doi.org/https://doi.org/10.22437/bio.v5i2.7590

Sadikin, A., Johari, A., \& Suryani, L. (2020). Pengembangan multimedia interaktif biologi berbasis website dalam menghadapi revolusi industri 4.0. Edubiotik: Jurnal Pendidikan, Biologi Dan Terapan, 5(01), 18-28. https://doi.org/10.33503/ebio.v5i01.644 
Sicat, A. S. (2015). Enhancing college students' proficiency in business writing via schoology. International Journal of Education and Research, 3(1), 159-178.

So, S. (2016). Mobile instant messaging support for teaching and learning in higher education. The Internet and Higher Education, 31, 32-42.

Staker, H. (2011). The Rise of K-12 Blended Learning: Profiles of Emerging Models. In Innosight Institute. ERIC.

Sun, P.-C., Tsai, R. J., Finger, G., Chen, Y.-Y., \& Yeh, D. (2008). What drives a successful e-Learning? An empirical investigation of the critical factors influencing learner satisfaction. Computers \& Education, 50(4), 1183-1202.

Wibowo, H. (2009). PEMBELAJARAN JARAK JAUH MENGGUNAKAN ELEARNING.

Yazdi, M., Matematika, D. J., \& Tadulako, U. (2012). E-LEARNING SEBAGAI MEDIA PEMBELAJARAN. 2(1), 143-152.

Zhang, D., Zhao, J. L., Zhou, L., \& Jay, F. N. (2004). J.(2004). Can e-learning replace classroom learning. Commun. ACM, 47(5), 75-79. 